\title{
狩猟採集民ムラブリの握力の発達に関する研究
}

\author{
大澤 清二（下田 敦子'シスコンタミット サターバン \\ プラディット ナリット
}

\section{A study on the development of muscle strength of hunter-gatherer Mlaburi in Thailand}

\section{Seiji Ohsawa ${ }^{1}$, Atsuko Shimoda ${ }^{1}$, Sataban SRISUKONTAMIT ${ }^{2}$ and Narits PRADITS ${ }^{2}$}

\begin{abstract}
This reports the results of analyzing the developmental process of muscular strength (grip strength) of Mlaburi people through infancy to adult ages.

1. The developmental process of muscular strength shows a sigmoid curve, so-called growth curve.

2 . Comparing by sex, men exceed women in every age class.

3 . The muscle development of men continues from 10 to around $20 \mathrm{yrs}$ old, and women from 8 to $17 \mathrm{yrs}$ old, including the adolescent spurt.

4. A small but apparent acceleration appears in men's infancy muscle development.

5. Grip strength-weight ratio was higher in Mlaburi group than in Japanese and Thai group in all age. This indicates that the environment of Mlaburi people required more physical use in their daily life.
\end{abstract}

Key words : Mlabri, hunter-gatherer, grip strength, muscle strength, physical fitness, motor development, Thailand

ムラブリ, 狩猟採集民, 握力, 筋力, 体力, 運動能力の発達, タイ

\section{I 研究の目的と意義}

ムラブリ人は 20 世紀の末まで，深い森を遊動 する生活者であり，狩猟採集民であった。 21 世紀 初頭の現在は定住を始めて日が未だ浅く，彼らが 現在まで生きてきた長大な時間からすれば定住生 活はまだわずかな時間しか経過していない。この 研究のねらいはムラブリ人の身体能力（ここでは 筋力）の発育過程を明らかにし，その背景となっ てきたムラブリ人の生活との関係を考え, さらに は俩猟採集という人類史における最も初期段階の 人の筋力発達を考える糸口を見出すことである.
私たちの先祖である石器時代人, 縄文人や古代 人はどのような身体能力を持っていたのだろう か. 子どもは自然の中でどのように発達したのだ ろうか. 現代に生きる研究者はその手がかりを現 代の狩猟採集民研究に求めることができるかもし れない.

幸いにもこれらのテーマを探求する上で好条件 のそろっているムラブリ人という民族集団が現在 タイの山中に生存している. 彼らはかつて, 周辺 の人々から幻の民, ピートンルアン (Phi Tong Luang, 黄色の葉の精霊) とも呼ばれていた時と ちがって，現在では定住をし始めた。そのおかげ

\footnotetext{
1 大妻女子大学人間生活文化研究所

${ }^{1}$ Institute of Human Culture Studies, Otsuma Women's University

${ }^{2}$ School Health Education Research Network in Asia
} 
で, 彼らの協力が得られれば, 研究対象として継 続的に聞き取り調查や測定を試みることが可能に なった。 そこで著者らは 2012 年から現地博物館, タイ政府の協力を経てムラブリ人の調査を継続し て行ってきた.

彼らの身体を知ることは人類社会の発展段階に おいて, 我々の祖先が移動生活から定住するよう になった時代の身体発育と発達を探求する貴重な 手がかりを与えてくれることが予想され，人の発 育発達の根源を探求する基礎資料を得ることがで きると期待される（大澤ほか, 2018）.

すでにタイ人研究者の Pookajorn（1992）とそ のチームは Ford 財団の支援の下で Ethnoarchaeology (人類考古学) の視点から, 森の奥梁くに 調査を行い, いくつかの興味深い先駆的な成果を 挙げてきた。ここで扱われた研究課題は言語, 家 族や親族, 経済や社会, 植物利用, 遺伝, 歯科, 食料，身体形質などであった．しかし収集されて いる身体発育や発達に関するデー夕は数例であっ て，ムラブリ人の幼児期から老年期にわたる生涯 全体を見渡せるデータは得られていないし, 発達 や老化の過程を議論するための資料も存在しな い.また近年では Trier and Jutland Achaeolorical Society（2008）が彼らの探検調査の一部である歯 科学的な調査結果と心理検査結果をその大きな著 作の付録として掲載したが，ここでもムラブリ人 の発育や発達には特別の関心は払われていない.

本研究ではムラブリ人を対象として筋力発達を 議論するのに十分なデー夕を収集して，これらの 基礎資料に基づてムラブリ人の筋力発達の実像 を明らかにする。

\section{II 研究方法}

\section{1. 調査対象, 解析データ}

ムラブリ人の 3 歳から 30 歳まで男 31 人, 女 37 人 (全人口が 300 人程度であるのでその約 $23 \%$ 程 度にあたる人々を測定することができた）を対 象とした。

測定は調查期間（2015 年から 2016 年）に 3 回 行っているが，測定日に定住地に滞在していない 人もいるので実際に得られたデー夕は合計男 83 サンプル，女 108 サンプルである．測定は基本的

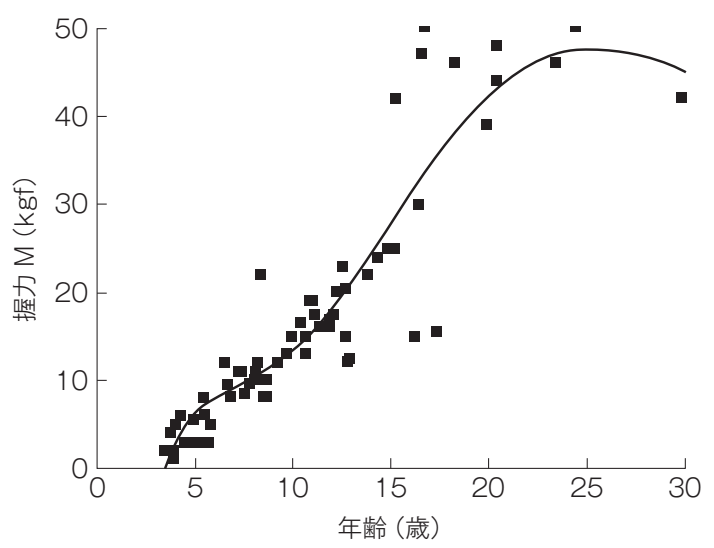

図 1 ムラブリ人 (男) の発育期の筋力発達（3 歳〜30 歳)

には午前中 9 時から 11 時までに実施した.

データセットは上記の測定データをプールして 構成したもので一種の mixed longitudinal study による資料である。

年齢の扱い方はすべての対象者の生年月日（夕 イ政府が行った調査によるデー夕を参考にした） と計測日から 10 進年齢に換算した。

なお, 調查に当たっては現地の夕イ政府公共福 祉局の調查許可を得たほか, 協力いただいた方々 の了解を得ている.

\section{2. 計測方法}

日本の新体力テスト実施要項に従った。 スメド レー式握力計で左右 2 回ずつ測定し, キログラム 未満もできるだけ正確に読み取るようにした，左 右とも最大值を採用しその平均を握力值として用 いた。 なお幼児〜10 歳については小児用の握力 計を使用した。

\section{3. 計測場所}

タイ国ナーン県バーンルアン郡プーケン村フア イユアックのムラブリ人の定住地内.

\section{4. 計測者}

著者らと訓練されたタイ国のヴェテラン体育教 員 1 名および現地在住の公務員と補助者. 


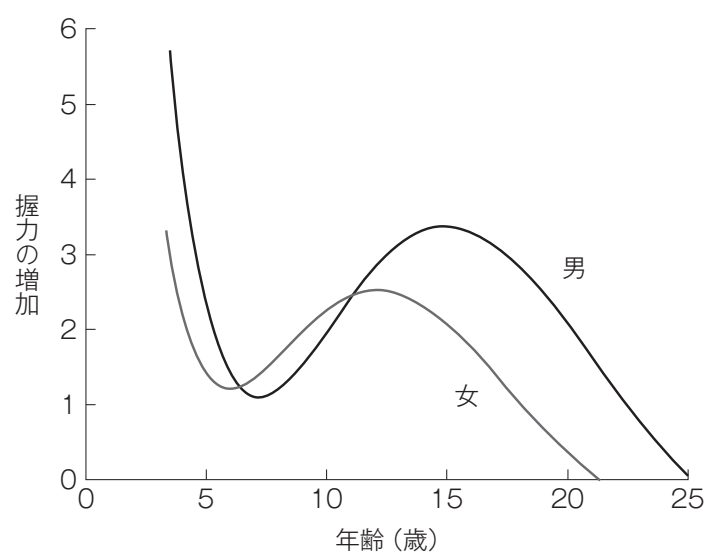

図 2 ムラブリ人の筋力発達速度曲線（男女）

\section{III 結 果}

\section{1. 男}

図 1 にムラブリ人の男の 3 歳から 30 歳までの 記録を示した。これらの測定值を用いて年齢に 沿って筋力を推定する発達関数を求めた. 結果と して 9 次多項式が最適の推定をもたらした. ここ で相関係数は $\mathrm{r}=0.954$ であり, 決定係数 $\mathrm{r}^{2}=$ (COD) 0.91066, 補正 $\mathrm{r}^{2}=0.90131$ である. した がって以下で用いる握力の推定值はかなり良好な 精度で計量されている。

ここで $\mathrm{x}$ は年齢, $\mathrm{y}$ は握力である.

(1) $\mathrm{y}=-51.60577+29.13868 \mathrm{X}-5.79992 \mathrm{X}^{2}$

$$
\begin{aligned}
& +0.59969 \mathrm{X}^{3}-0.03373 \mathrm{X}^{4}+0.00111 \mathrm{X}^{5} \\
& -2.17578 \mathrm{E}-5 \mathrm{X}^{6}+2.53523 \mathrm{E}-7 \mathrm{X}^{7} \\
& -1.61145 \mathrm{E}-9 \mathrm{X}^{8}+4.3054 \mathrm{E}-12 \mathrm{X}^{9}
\end{aligned}
$$

図 1 は上記（式 1）の推定值による筋力の発達 過程である。

まず発達曲線の形状は従来繰り返して報告され てきた筋力の発達曲線と大きく異なるものではな い. まず発達曲線は 3.0 歳の $0.5 \mathrm{~kg}$ から始まる. 4 歳で $2.7 \mathrm{~kg}, 4.5$ 歳で $4.7 \mathrm{~kg}$ という值が得られ るが, 5 歳未満の幼児の最大筋力值はムラブリ人 の場合にもやや信頼性がそしいかもしれない.し たがって，これらは参考值と言うべきであろう。

一般に握力に関する測定・研究は 5 歳もしくは 6 歳から行われており, 公表デー夕もそれにした がっている（Malina and Bouchrd, 1991; 猪飼・高 石, 1967 ; 文部科学省, 2017).
この調査ではできるだけ慎重に測定しているの で 5 歳あたりからはほほ信頼できると考えてい る. 5 歳では $6.2 \mathrm{~kg}, 6$ 歳で $7.9 \mathrm{~kg}, 7$ 歳では 9.1 $\mathrm{kg}, 8$ 歳で $10.2 \mathrm{~kg}$ となる.

8 歳からの発達曲線は緩やかに下に凸になり， 11 歳からは増加は加速している。この増加は 15 歳の $27.8 \mathrm{~kg}$ まで続く. 16 歳では $31.2 \mathrm{~kg}, 17$ 歳 で $34.4 \mathrm{~kg}, 18$ 歳で $37.3 \mathrm{~kg}, 19$ 歳で $40.0 \mathrm{~kg}$ とな る。しかし発達はここからもしばらく続き, 20 歳 で $42.3 \mathrm{~kg}, 21.5$ 歳には $45 \mathrm{~kg} に な り, 25$ 歳では $47.4 \mathrm{~kg}$ となり, これが. 男の最大值である.

次いで（式 1）を一階微分すると以下の（式 2) が得られる。

これは握力発達の速度を表現する。

(2) $\mathrm{y}=11.64102-5.35358 \mathrm{X}+0.9594 \mathrm{X}^{2}$

$$
\begin{aligned}
& -0.07792 \mathrm{X}^{3}+3.34 \times 10 \mathrm{E}-3 \mathrm{X}^{4} \\
& -8.13 \times 10 \mathrm{E}-4 \mathrm{X}^{5}+1.13 \times 10 \mathrm{EX}^{6}
\end{aligned}
$$$$
-8.31 \times 10 \mathrm{EX}^{7}+2.53 \times 10 \mathrm{E}-11 \mathrm{X}^{8}
$$

この一階微分後の式が描く握力発達曲線を図示 すると図 2 である.

筋力の発達速度は図 2 による以下のようで ある. まず最大の発達速度は 3 歳 4 歳の 5.7 $\mathrm{kg} /$ 年から始まり, 以降は急速に減少して 7 歳付 近でひとまず底をうつ。ここで幼児期から 7 歳か ら 8 歳までを最初の筋力発達の著しいフェーズと もいえる時期が存在すると言えそうである．前揭 の文献 (Malina and Bouchrd, 1991; 猪飼・高石, 1967 ; 文部科学省, 2017）ではこの部分のデータ が無いので幼児期の小さな筋力のスパートに関す る指摘はなされていない. 実はこのスパートは思 春期におけるスパートより重要な現象かもしれな いが, 今後の検討課題である.

7 歳からは, 再び発達速度は増してゆく.0 歳〜 11 歳で $2.0 \mathrm{~kg} /$ 年, 11 歳 12 歳で $2.5 \mathrm{~cm} /$ 年, 12 歳〜 13 歳で $2.8 \mathrm{~kg} /$ 年, 13 歳〜 14 歳で $3.2 \mathrm{~kg} /$ 年 と徐々にピークに接近し, 15 歳〜 16 歳で $3.4 \mathrm{~kg} /$ 年とピークに達する. 15 歳から発達速度は減少 して行くが，その勾配はかなり緩やかである。速 度が 0 になるのは男の場合は 25 歳である.

\section{2. 女}

図 3 に女の 3 歳から 30 歳までの全デー夕を示 した.これらを用いて最も当てはまりのよい発達 


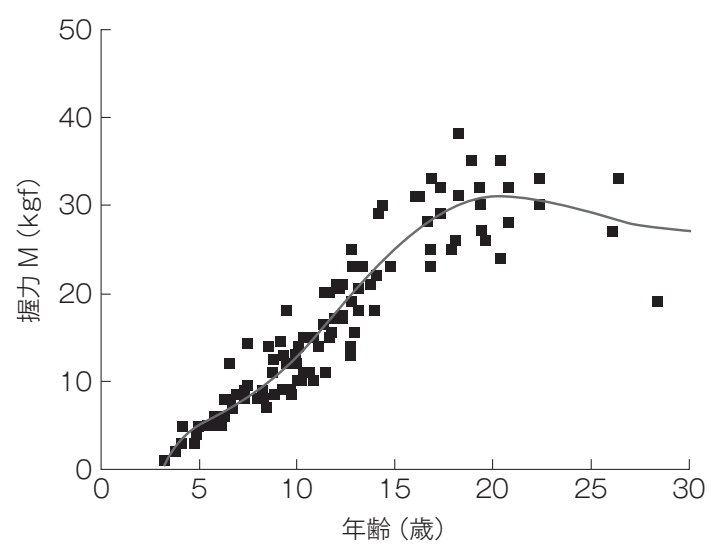

図 3 ムラブリ人（女）の発育期の筋力発達（3 歳〜30 歳）

関数を求めると, 9 次多項式が最適であった.

(3) $\mathrm{y}=-39.74428+25.32183 \mathrm{X}-5.86171 \mathrm{X}^{2}$

$$
\begin{aligned}
& +0.71673 \mathrm{X}^{3}-0.04819 \mathrm{X}^{4}+0.0019 \mathrm{X}^{5} \\
& -4.48923 \times \mathrm{E}-5 \mathrm{X}^{6}+6.29656 \mathrm{E}-7 \mathrm{X}^{7} \\
& -4.8201 \mathrm{E}-9 \mathrm{X}^{8}+1.55175 \mathrm{E}-11 \mathrm{X}^{9}
\end{aligned}
$$

この時の推定の精度は $\mathrm{r}=0.9540, \mathrm{r}^{2}=0.91026$, 補正 $\mathrm{r}^{2}=0.90342$ であって, 男の推定精度とほほ 同程度である。ここで X は年齢, $\mathrm{y}$ は握力である.

図 3 には推定式によって描かれた発達曲線が 示されている.

次いで,（式 3）を 1 階微分して発達速度を計算 すると, 以下の（式 4) が得られた.

(4) $\mathrm{y}=18.10502-10.5057 \mathrm{X}+2.2665 \mathrm{X}^{2}$

$$
\begin{aligned}
& -0.2252 \mathrm{X}^{3}+0.0119 \mathrm{X}^{4}-3.574 \times 10 \\
& -4 \mathrm{X}^{5}+6.11542 \times 10-6 \mathrm{X}^{6}-5.55504 \\
& \times 10-8 \mathrm{X}^{7}+2.07828 \times 10 \mathrm{X}^{8}
\end{aligned}
$$

この（式 4)をもとに発育速度をグラフにする と, 図 2 が得られる。

幼時期から 13 歳までの男女の筋力の発達曲線 の軌跡はほぼ似ている。しかし注意してみると, 5 歳からすでに男の発達はかなり傾斜が急である のに対して女のそれはやや緩やかである.13歳 までは男女の発達曲線の経過はおおむね同傾向を 示している. しかし 13 歳以降, 男は増加傾向が さらに増していくのに対して, 女の場合は 13 歳 を境に増加傾向が緩やかになる。これを推定值に よって追ってみると, 4 歳の $3.0 \mathrm{~kg}$ から 5 歳で $5.1 \mathrm{~kg}$ に増加する. 以降, 6 歳で $6.3 \mathrm{~kg}, 7$ 歳で は $7.5 \mathrm{~kg}, 8$ 歳で $8.8 \mathrm{~kg}$ となる.女では最初の筋
力発達のフェーズは男よりは早く終わっており， 6 歳から 12 歳までの発達曲線は緩やかに下に凸 の曲線で増加して行く. 12 歳の $19.0 \mathrm{~kg}$ あたり から上に凸の形状になって 13 歳 $20.3 \mathrm{~kg}, 14$ 歳 $22.8 \mathrm{~kg}, 15$ 歳 $25 \mathrm{~kg}, 16$ 歳 $27 \mathrm{~kg}, 17$ 歳 $28.5 \mathrm{~kg}$, 18 歳 $29.7 \mathrm{~kg}$, そして 19 歳から 21 歳の $30 \mathrm{~kg}$ ま で非常に緩やかに増加しつづける. 女子の筋力は 20 歳がピークで $31 \mathrm{~kg}$ である.

これを発達速度の視点で見ると，図 2 による と, 最大の発達速度は 3 歳から 4 歳の $3.3 \mathrm{~kg} /$ 年 の後で急速に減少して 6 歳付近で $1.1 \mathrm{~kg} /$ 年とな る，男の発達速度と同じく，女も幼児期に筋力の 発達の加速する時期があることは明らかである. 筋力発達の著しいフェーズの存在は男女とも認め られる。

再び 6 歳ころから発達速度は増加してピークは 12 歳〜 13 歳の $2.5 \mathrm{~kg}$ となる. この後, 発達速度 は緩やかになってゆき, 15 歳〜 16 歳では $2.0 \mathrm{~kg} /$ 年, 18 歳〜 19 歳で $1.0 \mathrm{~kg} /$ 年, 20 歳〜2 歳で 0.2 $\mathrm{kg} /$ 年である。減少過程は非常に緩やかであっ て，速度が 0 になるのは女の場合は 21.5 歳であ る.

発達速度曲線の特徵としては, 図 2 に見るよう に男では 15 歳を, 女では 12 歳を最大発達時期と して思春期の発達スパートと見られる現象が見ら れる。思春期においては男女ともに 1 回だけ大き なピークが存在するが，女のほうが男よりピーク の出現時期が 3 年ほど早く到来している。しかし ピークの山は男が $3.3 \mathrm{~kg} /$ 年であるのに対して女 は $2.5 \mathrm{~kg} /$ 年で少し小さい. ピーク出現の後は緩 やかに減少してゆき, 発達が終了するまではかな り長期間を要する.

\section{3. 性差について}

次に表 1 の推定值による男女の比較を行う. これによれば筋力は 3.5 歳から 4 歳までは女のほ うが大きい. 4.5 歳からは僅かに男のほうが大き くなり, 以降, 男が女を凌ぐ傾向は生涯続く. 14 歳以降は性差が次第に拡大し, 男と女の差は 14 歳で $1.7 \mathrm{~kg}$ と小さいが, 15 歳では $2.8 \mathrm{~kg}$ に広が り, 16 歳ではさらに $4.2 \mathrm{~kg}, 17$ 歳 $5.8 \mathrm{~kg}, 18$ 歳 $7.6 \mathrm{~kg}, 19$ 歳 $9.5 \mathrm{~kg}$ となり, 20 歳では $11.4 \mathrm{~kg}$, 21 歳 $13.2 \mathrm{~kg}, 22$ 歳 $14.9 \mathrm{~kg}, 23$ 歳 $16.3 \mathrm{~kg}, 24$ 歳 
表 1 ムラブリ人の握力の性差

\begin{tabular}{|c|c|c|c|}
\hline & 男 & 女 & 性差 \\
\hline 3.5 & 0.5 & 1.5 & -1.0 \\
\hline 4.0 & 2.7 & 3.0 & -0.3 \\
\hline 4.5 & 4.7 & 4.2 & 0.5 \\
\hline 5.0 & 6.2 & 5.1 & 1.1 \\
\hline 5.5 & 7.1 & 5.7 & 1.4 \\
\hline 6.0 & 7.9 & 6.3 & 1.6 \\
\hline 6.5 & 8.5 & 6.9 & 1.6 \\
\hline 7.0 & 9.1 & 7.5 & 1.6 \\
\hline 7.5 & 9.6 & 8.1 & 1.5 \\
\hline 8.0 & 10.2 & 8.8 & 1.4 \\
\hline 8.5 & 10.8 & 9.6 & 1.2 \\
\hline 9.0 & 11.6 & 10.5 & 1.1 \\
\hline 9.5 & 12.4 & 11.5 & 0.8 \\
\hline 10.0 & 13.4 & 12.6 & 0.8 \\
\hline 10.5 & 14.3 & 13.8 & 0.6 \\
\hline 11.0 & 15.6 & 15.0 & 0.6 \\
\hline 11.5 & 16.8 & 16.3 & 0.5 \\
\hline 12.0 & 18.3 & 17.5 & 0.7 \\
\hline 12.5 & 19.6 & 19.0 & 0.6 \\
\hline 13.0 & 21.3 & 20.3 & 1.0 \\
\hline 13.5 & 22.7 & 21.5 & 1.2 \\
\hline 14.0 & 24.5 & 22.8 & 1.7 \\
\hline 14.5 & 26.0 & 23.9 & 2.1 \\
\hline 15.0 & 27.8 & 25.0 & 2.8 \\
\hline 15.5 & 29.4 & 26.0 & 3.4 \\
\hline 16.0 & 31.2 & 27.0 & 4.2 \\
\hline 16.5 & 32.9 & 27.8 & 5.1 \\
\hline 17.0 & 34.4 & 28.5 & 5.8 \\
\hline 17.5 & 36.0 & 29.2 & 6.8 \\
\hline 18.0 & 37.3 & 29.7 & 7.6 \\
\hline 18.5 & 38.8 & 30.1 & 8.7 \\
\hline 19.0 & 40.0 & 30.5 & 9.5 \\
\hline 19.5 & 41.3 & 30.7 & 10.6 \\
\hline 20.0 & 42.3 & 30.8 & 11.4 \\
\hline 20.5 & 43.3 & 30.9 & 12.4 \\
\hline 21.0 & 44.1 & 30.9 & 13.2 \\
\hline 21.5 & 45.0 & 30.8 & 14.1 \\
\hline 22.0 & 45.6 & 30.7 & 14.9 \\
\hline 22.5 & 46.2 & 30.5 & 15.7 \\
\hline 23.0 & 46.6 & 30.3 & 16.3 \\
\hline 23.5 & 46.9 & 29.9 & 17.0 \\
\hline 24.0 & 47.2 & 29.7 & 17.5 \\
\hline 24.5 & 47.3 & 29.3 & 18.0 \\
\hline 25.0 & 47.4 & 29.0 & 18.4 \\
\hline
\end{tabular}

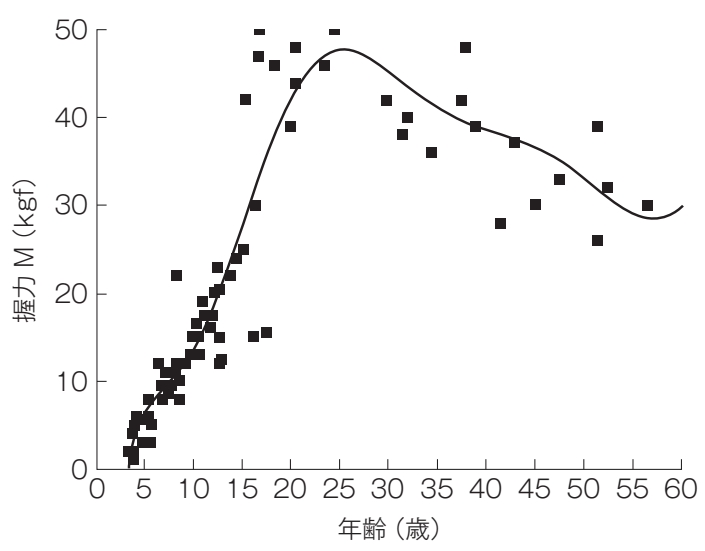

図 4 ムラブリ人 (男) の発育期の筋力発達（3 歳〜60 歳)

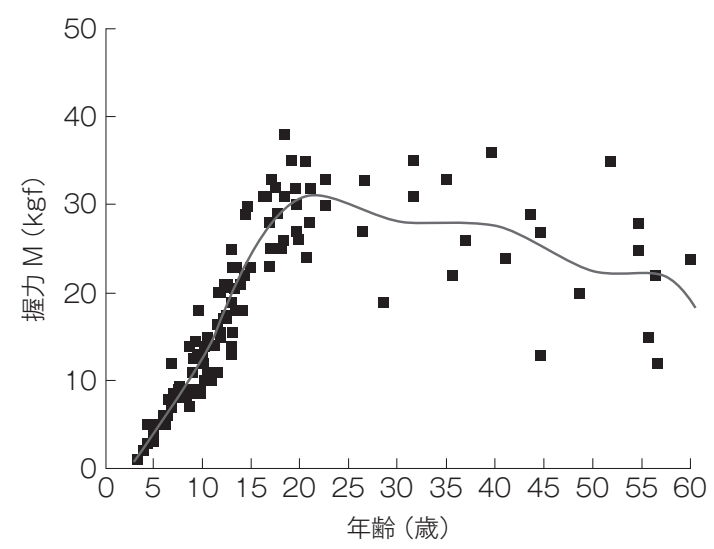

図 5 ムラブリ人（女）の発育期の筋力発達（3 歳 60 歳)

$17.5 \mathrm{~kg}, 25$ 歳では $18.4 \mathrm{~kg}$ に拡大している.

身長ではムラブリ人は幼児期から思春期の全期 間を通じて女のほうが男より大きかったが（大澤 ほか, 2018), 筋力では男のほうが一貫して大きい. これは従来より得られてきた知見と異なるところ ではない（森下, 1977）.

\section{4. 加齢に伴う筋力の変化}

男女の生涯にわたる筋力推定值を加齢に伴う変 化として追ってみる。男は図 4, 女は図 5 であ る。これによれば, 男では 20 歳台で最大值の $47.5 \mathrm{~kg}$ を示した後で, 次第に緩やかに低下して 行く. 37 歳で $40 \mathrm{~kg}, 40$ 歳では $38 \mathrm{~kg}, 50$ 歳で 33 $\mathrm{kg}, 55$ 歳くらいになると $29 \mathrm{~kg}$ 程度になる。

これに対して, 女では生涯の最大值は 21 歳の 
表 2 ムラブリ，タイ，日本における性別年齢別による握力を体重で除した平均値

\begin{tabular}{cllcccc}
\hline \multirow{2}{*}{ 年齢 } & \multicolumn{2}{c}{ ムラブリ } & \multicolumn{2}{c}{ タイ } & \multicolumn{2}{c}{ 日本 } \\
\cline { 2 - 7 } & 男子 & 女子 & 男子 & 女子 & 男子 & 女子 \\
\hline 3 & 0.176 & 0.130 & - & - & - & - \\
\hline 4 & 0.299 & 0.279 & - & - & - & - \\
\hline 5 & 0.356 & 0.366 & 0.363 & 0.377 & - & - \\
\hline 6 & 0.572 & 0.461 & 0.439 & 0.381 & 0.444 & 0.424 \\
\hline 7 & 0.564 & 0.507 & 0.469 & 0.358 & 0.468 & 0.442 \\
\hline 8 & 0.579 & 0.506 & 0.456 & 0.392 & 0.482 & 0.459 \\
\hline 9 & 0.599 & 0.516 & 0.429 & 0.407 & 0.482 & 0.470 \\
\hline 10 & 0.684 & 0.533 & 0.510 & 0.424 & 0.502 & 0.479 \\
\hline 11 & 0.701 & 0.591 & 0.521 & 0.498 & 0.524 & 0.497 \\
\hline 12 & 0.619 & 0.572 & 0.605 & 0.452 & 0.571 & 0.507 \\
\hline 13 & 0.772 & 0.506 & 0.653 & 0.529 & 0.622 & 0.523 \\
\hline 14 & 0.655 & 0.616 & 0.681 & 0.560 & 0.661 & 0.519 \\
\hline 15 & 0.825 & & 0.736 & 0.594 & 0.662 & 0.501 \\
\hline 16 & 0.750 & 0.632 & 0.746 & 0.612 & 0.683 & 0.513 \\
\hline 17 & 0.743 & 0.690 & 0.760 & 0.612 & 0.691 & 0.513 \\
\hline 18 & 0.866 & 0.733 & 0.794 & 0.620 & 0.686 & 0.516 \\
\hline 19 & 0.852 & 0.638 & 0.778 & 0.565 & 0.697 & 0.513 \\
\hline 20 & 0.861 & 0.677 & 0.804 & & 0.713 & 0.559 \\
\hline
\end{tabular}

$31 \mathrm{~kg}$ である. 25 歳では $30 \mathrm{~kg}$ になり，これ以降 もわずかに低下して 30 歳から 40 歳では $28 \mathrm{~kg}$ と なるが, 大きな変化はなくほぼ一定である。40歳 以降は測定值のばらつきが大きく，年齢的な変化 があるとは言いにくいが平均的には $23 \mathrm{~kg}$ 前後で ある. 加齢に伴う低下は男のほうが女より明瞭で ある。

\section{5. 体重あたりの握力から見たムラブリ人と 日本人, タイ人との比較}

筋力を身体の形質サイズとの対比から評価する ことがしばしば試みられてきた。古くは猪飼が前 掲文献の中で, 握力が身長の 3 乗と相関している ことをAsmussen らの研究を引いて紹介し, その 着眼のよいことを称賛している，ここでは「体重 当たりの握力值」と言う便宜的な指数を用いて考 察してみる。こうした指数は厳密には科学的な意 味は希薄であるが，筋力の相対的な民族間評価に は役立つ.ここでは日本人やムラブリ人の隣人で あるタイ人のそれと対比することで相対的にムラ
ブリ人の筋力の大きさを評価してみる.

筋肉は出生から成人に至るまでに 40 倍に増加 する。出生時には体重の $23.4 \%, 8$ 歳で $27 \%, 15$ 歳で $33 \%, 16$ 歳ころには成人と同じ $44 \%$ になり (猪飼・高石, 1967), 思春期は急速な筋肉の発達 を促すことがよく知られている.

表 2 は 6 歳から 30 歳までのムラブリ人男の握 力を体重で除した平均值である。ここでは日本人 の值を 2012 年度の文部科学省が公表した性・年 齢別平均值を用いている。 またタイ人の值（Ohsawa et al., 1985）をやや同時性にかけるが比較の ために揭載している.

これによれば，以下の観察が可能である.

(1)ムラブリ人男では 3 歳の 0.176 からはじま り, 4 歳 $0.299,5$ 歳 $0.356,6$ 歳 0.572 と急速に増 加する. 7 歳以降は上下動を繰り返しながらも少 しずつ増加して 10 歳では 0.6 になり, 11 歳では 0.7 に達する. 15 歳では 0.825 であり, 18 歳で 0.866 となりこれ以降は 25 歳の 0.965 と, ここで 計算した指数としては最大值になる. 
これに対して日本人は 6 歳が 0.444 であり, 日 本人の最大值である 20 歳の 0.713 との間を上下 するがほとんどの年齢で 0.6 台であって，ムラブ リと比べると全ての年齢で相対的には低い傾向で ある.さらにタイ人を比べてみると，ムラブリ人 より高かったのは 14 歳と 17 歳であるが他の年齢 ではムラブリ人よりも劣っている。これらの 3 群 の比較ではムラブリ人が最も体重あたりの筋力は 大きく，次いでタイ人，日本人の順である.

(2)ムラブリ人女では, 男と年齢に伴う変化は類 似して, 年齢とともに指数は大きくなってゆく. 3 歳 0.130 から 4 歳 $0.279,5$ 歳 $0.366,6$ 歳 0.4616, 7 歳 0.507 と急上昇している. これ以降 は 0.5 台が 13 歳まで続き, 14 歳に 0.616 となる. 15 歳は欠損值であるが, 18 歳には $0.733,22$ 歳で は 0.763 と最大值に至る.

これに対して日本人では 6 歳は 0.424 で始ま り, 11 歳まで 0.4 台である. 12 歳で 0.507 となっ て, 30 歳までずっと 0.5 台である. 全ての年齢で ムラブリ人のほうがはるかにこの指数は大きい.

タイ人は 12 歳までは, 日本人ょりも值は小さ く 13 歳で 0.529 と 3 群のうちで最大值を示し, これ以降で 19 歳まで日本人ょり大きい. ムラブ リ人は日本人や夕イ人より体重当たり筋力は優れ ている，また男は女よりも体重当たり筋力は大き w.

このように全年齢でムラブリ人は日本人や夕イ 人よりも体重当たりの大きな筋力を持っていると 推論することができる.

(3)このように観察すると, いずれの年齢でもム ラブリ人は日本人を凌いでおり, また夕イ人より も大きな筋力を持っていると推論することができ る.これは筋力あたりの体重という指数, つまり 1 単位あたりの筋力がどれだけの体重を支えられ るかにして比較しても事情は同じである.

\section{IV 考 察}

かつて Bernazik (1951) や Boeles (1963) はム ラブリ人を「Phi Tong Luang, 黄色の葉の精霊」 とタイ人たちの呼び方に倣って記述した。 それほ ど不思議な存在であったムラブリ人について彼ら は探検行を試み，ついに何名かのムラブリ人を捜
し当て，断片的な調查を敢行して旅行記を後世に 残した，彼らの著作によって啓発された研究者や 冒険家がその後同様の探検調查を試み, 徐々にム ラブリ情報が蓄積されてきた。最近では Pookajorn（1992）の報告が歯科学, 遺伝学に加えて形 質人類学的な観点からの知見を残してくれてい る.しかしデー夕数に限りがあり, 子どもの発育 や発達に関する記述はほとんど見られない。むろ んこれまでのムラブリ情報にもそうした発育や発 達に関するものは欠けている。まずは本研究のよ うな基礎的データの蓄積が無ければならない。こ の報告はまだ十全とは言えないが，ムラブリ人に 関する筋力発達に関する唯一の基礎資料である.

前述のように，ムラブリ人の幼児期から成人ま での筋力発達の過程は, 概観としては一般に発育 (成長) 曲線とも言われるシグモイド様の曲線を 示す.この点で従来の報告と大きな齟齬は無い. また，男女の比較をすると男が女を全ての年齢で 上回る成績を示している.

この 2 点でこれまで多くの国々，民族で報告さ れてきた一般的な知見と大きく異なるところは無 さそうである，ただし，思春期のスパートとも言 える発達の加速化は長期にわたっており, 男では 10 歳から 20 歳あたりまで, 女では 8 歳から 17 歳 くらいまでが該当すると言っても良い.この現象 は身長や体重などでも認められたムラブリ人の特 徵であると言っても良いかもしれない.さらに は，男の幼児期の発達に小さなスパートらしき曲 線の盛り上がりが認められる点に注目しておきた い.

また，最後に検討したように体重当たりの握力 比では日本人のそれより発達段階のどこでも優れ ていた．栄養摂取や体力つくりの機会も行き届 き，さまざまな身体保護の環境に恵まれた日本人 と比べると, 格段に貧しく, 体力つくりなどまっ たく意識としても存在しないムラブリ人のほうが 筋力ではるかに優れていることは彼らの生活にお いて常に身体を用いることを必要としている環境 と深く関係していよう。

さらに発達過程の途上において子どもの遊び自 体が野外における身体を使用したものであること とも無関係ではなかろう。ムラブリの子どもの遊 びにおいても殆どは身体性を伴っているもので 


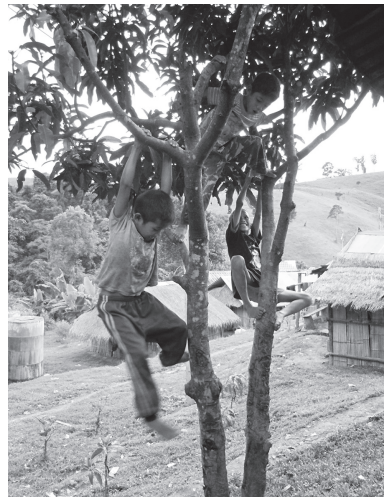

写真 1 木登り

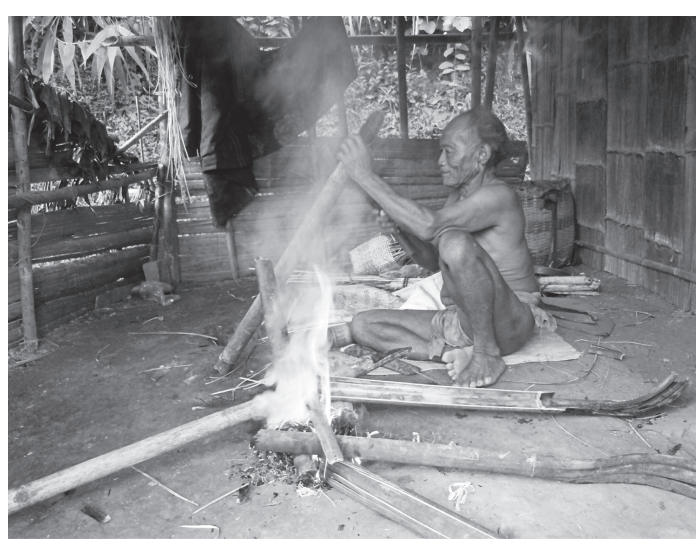

写真 2 囲炉裏に火をおこす
あったことも見逃せない (大澤ほか, 2015)。写真 の木登りは彼らの日常でしばしば見られる行動で あるが，木登りは遊びでもあり生業でもある（写 真 1). 大人においても蜂蜜採りや木の実の収穫 に際して体重を四肢の筋力で支持し，木を昇降す るために不可欠なのは筋力である，彼らの日常の 行動は, 裸足で急な傾斜地や森の中を歩きまわり, 走り，危険を及ぼしそうな動物から逃げたり，イ ノシシやネズミ, 蛇などを追って捕獲し, 家をつ くり, 果物や木の実を採取し, 芋など手で掘り返 し，小川で魚や蟹などを生け捕り，食料を別き， 囲炉裏に火をおこし，(写真 2) 調理をする。これ らの生活行動はすべて自分自身の身体の力に依存 している.もちろん彼らは長い間, 移動は徒歩で のみ行い. 動物を家畜化して使役することもしな かったのである。

身体の在り方という点で，ムラブリ人と文明世 界に生きてきた現代人は双極をなすように対照的 である。ムラブリ人の「身体」を知ることには現 代の我々が「身体」とは何か，について本質的な 問題を解く鍵が潜んでいると考えられ，発育や発 達についても原始の状態で狩猟採集生活してきた 人々を研究することで得られるものは少なくない はずである。

\section{付 記}

なお，この研究課題は科研費-基盤研究（A）「人が 生育する限界的環境に於ける発育発達（生活技術の発 達を含む) と成熟の総合的研究 (15H01763) 研究代表
者: 大澤清二」「アジア採集狩猟民児童〜大都市児童 の発育発達多様性と環境の相互作用, 含む標準值作製 (23240098) 研究代表者: 大澤清二」と挑戦的萌芽研究 「僧院に扔ける統制されたライフスタイルが少年僧の 発育発達に及ぼす影響（26560028）研究代表者：大澤 清二」, 基盤研究（B）「ミャンマー 135 民族の民族服 製作技術の残存調查と技術学習過程の最適化方法論 の開発（18H00967）研究代表者：下田敦子」の補助を 受けたことを付記する.

\section{文献}

Bernazik, H. A. (1958) The Spirit of the Yellow Leaves, Robert Hale Ltd. (大林太良訳（1968）黄色い葉の 精霊, 東洋文庫, 平凡社)

Boeles, J. J. (1963) Second expedition to the Mrabri (Khon Pa) of North Thailand, Journal of Siam Society, 51, 133-160

猪飼道夫, 高石昌弘（1967）身体発達と教育, 第一法 規出版， $165-179$

Malina, R. M. and Bouchrd, C. (1991) Growth, Maturation and Pysical Activity, Human Kinetics, 187204

森下はるみ（1977） スポーツと年齢, 高石昌弘, 宮下 充正編, 講座現代のスポーツ科学 4 , 大修館書店, 23

大澤清二 (2016) 人類発達史からみた身体発達研究の 課題, 子どもと発育発達， 14，42-49

大澤清二, 下田敦子, 二文字屋脩（2015）狩临採集民 ムラブリの子どもの遊びに関する記述的研究, 発 育発達研究， $66 ， 1-15$

大澤清二, 下田敦子, シスコンタミット $\mathrm{S}$, プラディッ 
ト N（2018）思春期の身長発育スパートが見られ ないムラブリ人について, 発育発達研究, 80, 3038

Ohsawa, S, Sagawa, T.,Kokudo, S. (1985) Ubon Child Motor Development Study, Institute of Human Living Sciences, Otsuna Women's University, 3435

Pookajorn, S. (1992) The Phi Tong Luang (Mlabri), Hunter-Gatherer Group in Thailand, Odeon Store
Trier, J. and Jutland Achaeolorical Society (2008) Invoking the Spirit, Jutland Archaeological Society Publication, 60, 1-332

文部科学省（2017）平成 28 年度体力・運動能力調查, https://www.e-stat.go.jp/stat-search/files? page $=1 \&$ layout $=$ datalist\&toukei $=00402102 \&$ tst at $=000001088875 \&$ cycle $=0 \&$ tclass $1=0000011$ $07355 \&$ second $2=1$ (参照日 : 2018 年 6 月 30 日） (受付 : 2018 年 7 月 1 日, 受理 : 2018 年 7 月 24 日)

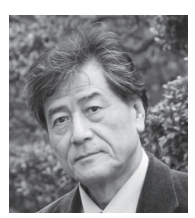

大澤 清二（おおさわ せいじ）

現職 : 大妻女子大学副学長, 理事, 人間 生活文化研究所長, 博物館長, 総 合情報センター所長, 日本発育発 達学会会長, International Journal of Human Culture Studies 編集長

1946 年生まれ，東京大学大学院修了 (教育学博士). 筑波 大学専任講師, 東南アジア医療情報センター専門員を経て, 1988 年より大妻女子大学に奉職.

現在は狩猟採集民モーケンやムラブリをはじめとして東南 アジア諸民族の発達調查を行っている. 